\title{
The effect of plant age on the chemical composition of fresh and ensiled Agave salmiana leaves
}

\author{
J.M. Pinos-Rodríguez ${ }^{1,2 \#}$, M. Zamudio ${ }^{3}$ and S.S. González ${ }^{4}$ \\ ${ }^{1}$ Instituto de Investigación de Zonas Desérticas, Universidad Autónoma de San Luis Potosí, San Luis Potosí, S.L.P. \\ 78377, México \\ ${ }^{2}$ Ohio Agriculture Research and Development Centre, The Ohio State University. Wooster, OH. 44691, USA \\ ${ }^{3}$ Departamento de Producción Agrícola y Animal, Universidad Autónoma Metropolitana. D.F. 04960, México \\ ${ }^{4}$ Ganadería, Colegio de Posgraduados, Montecillo, 56230, México
}

\begin{abstract}
In the first study dry matter (DM), organic matter, crude protein (CP), neutral detergent fibre (NDF) and soluble carbohydrate (SC) concentrations were determined in whole leaves and the upper and lower sections of whole leaves of the Agave salmiana (Otto ex. Salm-Dyck) plant. The $\mathrm{pH}$ and saponin concentration were measured in aqueous extracts from these leaves. The leaves were collected from plants at the young (ca. 12 years old), bud (ca. 14 years old) and mature (ca. 16 years old) stages of growth. The CP level of young Agave (48 g/kg DM) leaves was higher than in leaves from the bud ( $38 \mathrm{~g} / \mathrm{kg} \mathrm{DM}$ ) and mature (43 g/ $/ \mathrm{kg} \mathrm{DM})$ stages, and higher in the upper $(51 \mathrm{~g} / \mathrm{kg} \mathrm{DM})$ than in the lower $(35 \mathrm{~g} / \mathrm{kg} \mathrm{DM})$ leaf sections. The leaves at the bud stage contained lower NDF (189 g/kg DM) but higher SC (358 g/kg DM) levels than those of mature (272 g NDF, $247 \mathrm{~g} \mathrm{SC} / \mathrm{kg} \mathrm{DM}$ ) and young (273 g NDF, $189 \mathrm{~g} \mathrm{SC}$ ) plants. The saponin content of leaves was higher in the mature $(11.1 \mathrm{~g} / \mathrm{kg} \mathrm{DM})$ than in the bud stage $(7.5 \mathrm{~g} / \mathrm{kg} \mathrm{DM})$. In the second study the chemical composition of whole leaves from young, bud and mature micro-ensilaged $(3.5 \mathrm{~kg}$ as fed) Agave was determined over a 36 weeks fermentation period. Agave silage had acceptable chemical characteristics. As time of fermentation increased, a linear decrease in DM and saponin concentration, a linear increase in NDF and lactic acid levels and a quadratic increase of $\mathrm{pH}$ values and ammonia-N concentrations were recorded. Both fresh and ensilaged leaves of the mature and the bud stages were the most desirable maturity stages of Agave to be utilised as feed for ruminants.
\end{abstract}

Keywords: Agave salmiana, chemical composition, maguey

" Corresponding author. E-mail: jpinos@uaslp.mx

\section{Introduction}

In arid and semi-arid areas of Mexico Agave spp., Opuntia spp. and Yucca spp. are important sources of nutrients, especially water, for humans and animals. These plants are widely distributed and adapted to harsh environmental conditions. Agave salmiana, a non-cultivated plant, is the main source of sugars (ca. $500 \mathrm{~g}$ non-structural carbohydrates per $\mathrm{kg}$ dry matter (DM)) to produce mescal, an alcoholic beverage obtained by distilling fermented Agave juice (Wang \& Nobel, 1998; Pinos-Rodriguez et al., 2006; 2007). Agave salmiana has a large rosette of thick fleshy leaves, each ending generally in a sharp point and with a spiny margin; the stout stem is usually short, the leaves apparently springing from the roots. A wild Agave starting its reproductive phase (shoot apex thinned at its base, and youngest leaves shorter and displaying black and shiny spines) is called "bud". After the bud stage the apical meristem is removed, and the plant is considered "castrated". One year following castration, Agave is considered mature and ready to be harvested (Aguirre et al., 2001). Thus, under average environmental conditions such as the semi-arid areas in northern Mexico, wild A. salmiana reaches maturity at ca. 16 years (Aguirre et al., 2001).

During the dry season (October - March) A. salmiana leaves are used as feed for cattle and goats, containing ca. $800 \mathrm{~g}$ water $/ \mathrm{kg}$ and $<40 \mathrm{~g}$ crude protein $(\mathrm{CP}) / \mathrm{kg} \mathrm{DM}$. However, there is little information on the chemical composition of Agave at the different maturity stages (Pinos-Rodríguez et al., 2006; 2007; Silos-Espino et al., 2007), though mature plants would be more desirable as an animal feed because the sap in young Agave plants has a high content of calcium oxalate crystals, acrid oils and saponins (Salinas et al., 2001). The objective of this study was to determine the chemical composition of the leaves and leaf sections 
from young, bud and mature fresh Agaves, as well as the chemical composition of Agave leaves ensiled for 36 weeks.

\section{Materials and Methods}

Leaves from wild specimens of the plant A. salmiana (Otto ex. Salm Dyck) were collected at Ipiña, Ahualulco, San LuisPotosí in central Mexico between latitudes $24^{\circ} 29^{\prime} \mathrm{N}$ and $21^{\circ} 10^{\prime} \mathrm{N}$ and longitudes $98^{\circ} 20^{\prime} \mathrm{W}$ and $102^{\circ} 18^{\prime} \mathrm{W}$. This site has an arid climate with an average annual temperature of $16.8^{\circ} \mathrm{C}$ and an average annual rainfall of $389 \mathrm{~mm}$. Most of the precipitation is between September to November, and spring is a dry season.

Leaves from Agave plants were collected at three maturity stages: young (ca. 12 years old), bud (ca. 14 years old) and mature (ca. 16 years old) stages. In the first study three A. salmiana plants from each of the three maturity stages were selected randomly. From each plant, all leaves were cut in two symmetric transverse sections, the lower and upper sections. Samples of each section were cut (length, $2 \mathrm{~cm}$ ) with a knife, dried $\left(55^{\circ} \mathrm{C}, 48 \mathrm{~h}\right)$ and ground $(1 \mathrm{~mm})$. Dry matter, organic matter $(\mathrm{OM})$ or ash and $\mathrm{CP}(\mathrm{N} \times 6.25)$ were analyzed according to AOAC (1995). Neutral detergent fibre (NDF) was assayed without heat stable amylase and expressed inclusive of residual ash (Van Soest et al., 1991). Aqueous extracts from fresh samples were used to determine $\mathrm{pH}$ values and saponin concentrations. A portable $\mathrm{pH}$ meter $(\mathrm{pH}$ meter, OAKTON, Vernon Hills, IL, USA) was used for $\mathrm{pH}$ determinations. Saponins were determined with a spectrophotometer (430 nm; UV-VIS Agilent 8453, Santa Clara, CA) using anisaldehide and diosgenin (Sigma Chemical Co., St. Louis, MO) as colour reagents (Baccou et al. (1977). Soluble carbohydrates (SC) from dried samples were analyzed (Dubois et al., 1956) using a colorimetric method (490 nm; UV-VIS Agilent 8453, Santa Clara, CA) with glucose (Merck, Darmstadt, Germany) to obtain a calibration curve.

In a second study, nine Agave plants (three of each maturity stage) were harvested randomly. Whole leaves from each plant were ground $(20 \mathrm{~mm}$, using a chopper, Aztec, Aguascalientes, Mexico) separately. Fourteen micro-silos ( $3.5 \mathrm{~kg}$ as fed) per maturity stage were made using black PVC ( $1 \mathrm{~mm}$ thick). The micro-silos were compacted with a manual press and kept outdoors $\left(13-32{ }^{\circ} \mathrm{C}\right)$ for a $0,1-, 2-, 3-, 4-, 5-$ or 36 -week fermentation period. Three silos per maturity stage corresponding to each fermentation time $(0,1,2$, $3,4,5$, and 36 weeks) were opened; samples were taken and analyzed as described for the first study.

Additionally, aqueous extracts from the silage were acidified with $3 \mathrm{M}$ metaphosphoric acid (1:4 dilution), cooled $\left(4{ }^{\circ} \mathrm{C}\right)$ for $5 \mathrm{~h}$ and centrifuged $\left(3,000 \mathrm{~g} ; 4{ }^{\circ} \mathrm{C} ; 30 \mathrm{~min}\right)$. Supernatants were removed and samples were frozen $\left(-4^{\circ} \mathrm{C}\right)$. Concentrations for volatile fatty acid (VFA; Erwin et al., 1961), ammonia-N $\left(\mathrm{NH}_{3} \mathrm{~N}\right.$; McCullough, 1967) and lactic acid (Madrid et al., 1999) concentrations were determined.

The experimental design of the first study was completely randomized with a factorial arrangement of treatments ( $3 \times 2)$ : maturity (young, bud and mature) and leaf section (lower and upper). Main effects and interaction were analyzed using the 'GLM' option of SAS (1999), and the 'LSMEANS' option (SAS, 1999) was used to compare means. The statistical model was: $Y_{i j k}=\mu+A_{i}+B_{j}+(A B)_{i j}+\varepsilon_{i j}$, where: $\mu=$ overall mean, $A_{i}=$ maturity effect $(i=1,2,3) ; B_{j}=$ leave section effect $\left.(j=1,2) ;(A B)\right)_{i j}=$ interaction effect of $A_{i}$ and $\mathrm{B}_{\mathrm{j}}$ and $\varepsilon_{\mathrm{ij}}=$ random error. The experimental design of the silage study was a complete randomized design with a factorial arrangement of treatments ( $3 \times 7)$ : maturity (young, bud and mature), and fermentation week $(0,1,2,3,4,5,36)$. Main effects and interaction were analyzed using the 'GLM' option of SAS (1999), and the 'LSMEANS' option (SAS, 1999) were used to compare means of maturity stages. The fermentation week effect was analyzed with orthogonal polynomials (linear, quadratic and cubic) calculating coefficients with the 'IML' option of SAS (1999). The statistical model was: $Y_{i j k}=\mu+A_{i}+B_{j}+(A B)_{i j}+\varepsilon_{i j}$, where: $\mu=$ overall mean, $A_{i}=$ maturity effect $(i=1,2,3) ; B_{j}=$ fermentation week effect $(j=1,2,3,4,5,6,7) ;(A B)_{i j}=$ interaction effect of $A_{i}$ and $B_{j}$ and $\varepsilon_{i j}=$ random error.

In both studies significant differences were accepted at $\mathrm{P}<0.05$. Because no maturity and leaf section interactions or maturity and fermentation week interactions were obtained, only overall main factors are presented.

\section{Results}

The chemical composition of fresh Agave leaves is shown in Table 1. Maturity impacted $(\mathrm{P}<0.05)$ on $\mathrm{DM}, \mathrm{OM}, \mathrm{CP}, \mathrm{NDF}$, ash, $\mathrm{SC}$ and saponin content, but not on $\mathrm{pH}$ values. Leaf section impacted $(\mathrm{P}<0.001)$ $\mathrm{CP}$ content and $\mathrm{pH}$ values. No interactions were found between maturity and leaf section. Crude protein 
content of young leaves was higher $(\mathrm{P}<0.05)$ than those of leaves from the bud stage. The $\mathrm{CP}$ content of the upper leaf section was higher than in the lower leaf section. Leaves from the bud stage had a lower $(\mathrm{P}<0.001)$ NDF but a higher $(\mathrm{P}<0.001) \mathrm{SC}$ content than those from mature or young plants. The saponin content of mature Agave leaves was higher $(\mathrm{P}<0.001)$ than that of plants in the bud stage.

The chemical composition of Agave leaf silage is presented in Table 2. Maturity affected $(\mathrm{P}<0.05)$ only $\mathrm{OM}$ and saponin content, since content of $\mathrm{OM}$ was higher in mature compared to young leaves. Saponin concentration was higher in the bud than in the young or mature leaves. Concentration of volatile fatty acids in the silage was not affected by maturity stage.

Changes in chemical composition of the ensiled Agave leaves over time are shown in Table 3. During the first four weeks of fermentation, DM in Agave silage decreased sharply, and then remained relatively constant until week 36. In the first week of fermentation, NDF concentration increased sharply, and increased steadily until week 36. There was a linear decrease of saponin concentration as weeks of fermentation increased. The $\mathrm{pH}$ values were sharply reduced in the first week of fermentation, followed by mild decreases until week 3, without any further changes. Lactic acid concentrations increased linearly with time. Ammonia-N concentrations did not change in the first two weeks, increased sharply in the third week, without further changes afterwards.

\section{Discussion}

The chemical composition of Agave leaves recorded in this study is similar to those found by PinosRodriguez et al. $(2006 ; 2007)$. However, DM content was lower than reported previously. This could be due to the fact that the Agave plants were collected during the rainy season (September) and these Crassulacean acid metabolism (CAM) plants have a high capacity for storing water (Nobel \& Meyer, 1985). Differences in the $\mathrm{OM}$ and $\mathrm{CP}$ levels found in the bud and mature compared with those in young Agave leaves might be related to higher concentrations of SC. Leaves of Agave plants have a low photosynthetic activity that is involved in the enzymatic process to store SC (Nobel \& Meyer, 1985). Thus, CP levels in the leaves of Agave plants in the bud and mature stages were higher and contained more SC than leaves during the young stage.

In this study SC concentrations were higher $(\mathrm{P}<0.001)$ in bud than in mature leaves, which does not agree with Aguirre et al. (2001) who found a higher SC in mature Agaves. However, they determined SC only in the lower section of the leaves but included the stem, whereas in this study only whole leaves were analysed. This higher CS concentration in the lower than upper leave section has been previously reported in A. tequilana (Iñiguez-Cobarrubias et al., 2001), but in this study there were no differences in the CS concentration between lower and upper leaf sections. The mean SC concentrations of mature, bud and young Agave plants found in this study (265 g/kg DM) are low in comparison to those reported by Aguirre et al. (2001). This could be because these authors determined SC in the stem plus the lower section of the leaf, whereas in the present study SC was determined on leaves without stems.

Since NDF concentration was higher $(\mathrm{P}<0.001)$ in the young than in the mature and bud stages, cell wall accumulation in Agave plants would be different to that in other plants where NDF concentration increases with maturity (Van Soest, 1994). This is also a consequence of a high accumulation of SC in Agaves. Saponin concentrations of leaves in the mature and young stages were similar, but lower $(\mathrm{P}<0.001)$ in the bud stage than in the mature plant. There is a trend of a higher concentration of saponins in young as compared to mature plants (Francis et al., 2002).

The $\mathrm{pH}$ values found in this experiment agree with values reported by Pinos-Rodriguez et al. (2007). The low $\mathrm{pH}$ in Agaves could be due to the fact that the optimum $\mathrm{pH}$ for enzymes involved in CAM is 2 or 3 fold lower than in most C3 or C4 plants (Salisbury \& Ross. 1991) such as ryegrass (Davies et al., 1998), maize (Johnson et al., 2002) and barley (Mustafa et al., 2002).

In this study the DM content in the silages was lower than that recommended by McDonald (1981) who suggested a DM content of $c a .300 \mathrm{~g} / \mathrm{kg}$ to obtain silage with acceptable chemical and physical characteristics. Agave silages contained low butyrate concentrations from the first week of fermentation (Table 2). This suggested that the SC content in fresh Agave was enough to produce the amount of 
Table 1 Mean chemical composition of fresh leaves from the mature, bud and young growth stages of Agave salmiana, and the lower and upper sections of the leaves

\begin{tabular}{|c|c|c|c|c|c|c|c|c|c|c|}
\hline & \multicolumn{4}{|c|}{ Maturity } & \multicolumn{3}{|c|}{ Leaf section } & \multicolumn{3}{|c|}{ Significance $^{1}$} \\
\hline & Mature & Bud & Young & s.e.m. & Lower & Upper & s.e.m. & Maturity & Section & Interaction $^{2}$ \\
\hline Dry matter, $\mathrm{g} / \mathrm{kg}$ & $105^{b}$ & $130^{\mathrm{a}}$ & $110^{\mathrm{b}}$ & 50.4 & 111 & 119 & 41.1 & $* * *$ & NS & NS \\
\hline Organic matter, g/kg DM & $914^{\mathrm{a}}$ & $916^{\mathrm{a}}$ & $862^{b}$ & 69.7 & 901 & 894 & 56.9 & $* * *$ & NS & NS \\
\hline Crude protein, $\mathrm{g} / \mathrm{kg} \mathrm{DM}$ & $43^{\mathrm{ab}}$ & $38^{\mathrm{b}}$ & $48^{\mathrm{a}}$ & 2.4 & 35 & 51 & 1.9 & $*$ & $* * *$ & NS \\
\hline Neutral detergent fibre, $\mathrm{g} / \mathrm{kg} \mathrm{DM}$ & $272^{b}$ & $189^{\mathrm{b}}$ & $273^{a}$ & 11.1 & 245 & 244 & 9.1 & $* * *$ & NS & NS \\
\hline Ash, g/kg DM & 86 & 84 & 138 & 6.2 & 99 & 106 & 5.1 & $* * *$ & NS & NS \\
\hline Soluble carbohydrates, $\mathrm{g} / \mathrm{kg} \mathrm{DM}$ & $247^{\mathrm{b}}$ & $358^{\mathrm{a}}$ & $189^{c}$ & 23.3 & 278 & 252 & 19.1 & $* * *$ & NS & NS \\
\hline Saponins, g/kg DM & $11.1^{\mathrm{a}}$ & $7.5^{b}$ & $8.9^{\mathrm{ab}}$ & 0.75 & 8.2 & 10.1 & 0.62 & $* * *$ & $*$ & NS \\
\hline $\mathrm{pH}$ & 4.9 & 4.9 & 4.9 & 0.03 & 5.0 & 4.9 & 0.02 & NS & $* * *$ & NS \\
\hline
\end{tabular}

$\overline{\mathrm{a}, \mathrm{b}, \mathrm{c}}$ Means in the same row within maturity stages with different superscripts differ at $\mathrm{P}<0.05$

${ }^{1} \mathrm{NS}=$ non significant; $*=\mathrm{P}<0.05 ; * *=\mathrm{P}<0.01 ; * * *=\mathrm{P}<0.001$.

${ }^{2}$ Maturity x leaf section. 
Table 2 Mean chemical and volatile fatty acid composition of silage from young, bud and mature Agave salmiana leaves

\begin{tabular}{|c|c|c|c|c|c|c|c|}
\hline & \multicolumn{4}{|c|}{ Maturity } & \multicolumn{3}{|c|}{ Significance $^{1}$} \\
\hline & Young & Bud & Mature & s.e.m. & Maturity & Week & Interaction $^{2}$ \\
\hline Dry matter, $\mathrm{g} / \mathrm{kg}$ & 152 & 154 & 151 & 6.8 & NS & $*$ & NS \\
\hline Organic matter, g/kg DM & $875^{b}$ & $901^{\mathrm{ab}}$ & $929^{a}$ & 73.3 & $*$ & $*$ & NS \\
\hline Crude protein, $\mathrm{g} / \mathrm{kg} \mathrm{DM}$ & 37 & 35 & 36 & 2.3 & NS & NS & NS \\
\hline Neutral detergent fibre, $\mathrm{g} / \mathrm{kg} \mathrm{DM}$ & 370 & 322 & 347 & 22.3 & NS & $* * *$ & NS \\
\hline Saponins, g/kg DM & $4.4^{\mathrm{b}}$ & $6.3^{\mathrm{a}}$ & $4.6^{\mathrm{b}}$ & 0.57 & $*$ & $* * *$ & NS \\
\hline $\mathrm{pH}$ & 3.7 & 3.8 & 3.9 & 0.07 & NS & $* * *$ & NS \\
\hline Ammonia-N, mg/g N & 84 & 60 & 61 & 16.7 & NS & $* *$ & NS \\
\hline Lactic acid, g/kg DM & 122 & 145 & 116 & 10.2 & NS & $* * *$ & NS \\
\hline Acetate, g/ kg DM & 41 & 42 & 40 & 5.0 & NS & NS & NS \\
\hline Propionate, g/ kg DM & ND & 0.8 & 1.1 & & & & \\
\hline Butyrate, g/ kg DM & ND & 0.5 & 0.3 & & & & \\
\hline
\end{tabular}

$\overline{\mathrm{a}, \mathrm{b}}$ Means in the same row with different superscripts differ $(\mathrm{P}<0.05)$.

${ }^{1} \mathrm{NS}=$ non significant; $*=\mathrm{P}<0.05 ; * *=\mathrm{P}<0.01 ; * * *=\mathrm{P}<0.001 .{ }^{2}$ Maturity $\mathrm{x}$ fermentation week; ND - means not detected.

Table 3 Changes in chemical composition of Agave salmiana leaf silage during 0 to 36 weeks of fermentation

\begin{tabular}{|c|c|c|c|c|c|c|c|c|c|}
\hline & \multicolumn{7}{|c|}{ Week of fermentation } & \multirow[b]{2}{*}{ s.e.m. } & \multirow[b]{2}{*}{$\mathrm{P} \leq 0.05$} \\
\hline & 0 & 1 & 2 & 3 & 4 & 5 & 36 & & \\
\hline Dry matter, $\mathrm{g} / \mathrm{kg}$ & 164 & 158 & 154 & 150 & 148 & 147 & 145 & 3.94 & Linear \\
\hline Neutral detergent fibre, $\mathrm{g} / \mathrm{kg} \mathrm{DM}$ & 269 & 313 & 333 & 348 & 361 & 380 & 395 & 12.88 & Linear \\
\hline Saponins, g/kg DM & 6.1 & 5.8 & 5.4 & 5.3 & 5.0 & 4.5 & 3.4 & 0.33 & Linear \\
\hline $\mathrm{pH}$ & 4.70 & 3.87 & 3.66 & 3.60 & 3.58 & 3.57 & 3.60 & 0.026 & Quadratic \\
\hline Ammonia- $\mathrm{N}, \mathrm{mg} / \mathrm{g} \mathrm{N}$ & ND & 67 & 69 & 83 & 85 & 87 & 89 & 4.01 & Quadratic \\
\hline Lactic acid, g/kg DM & ND & 94 & 109 & 125 & 138 & 141 & 149 & 8.41 & Linear \\
\hline
\end{tabular}


lactic acid necessary to reduce $\mathrm{pH}$ and prevent Clostridium bacterial growth, such as had been found in ryegrass (Davies et al., 1998). An undesirable physical characteristic observed, but not measured, was the high quantity of effluent produced by Agave silages. Effluent production is negatively correlated with DM content (Frasen \& Strubi, 1998) and positively correlated with nutrients loss or solubility as non-structural carbohydrates (Savoie et al., 2002; Yahaya et al., 2002). A reduction of moisture in fresh Agave could be an option to reduce effluent, as has been done with other forages (McDonald, 1981).

Contrary to common forages, Agave maturity did not affect the chemical composition of the silage. This may be a result of the higher SC concentration that can be converted to lactic acid in mature or bud stages as compared to young Agaves. This is in agreement with results found by Pinos-Rodriguez et al. (2007), but is higher than those reported in grass (Cherney et al., 2004) and maize silages. This could be due to its low buffering capacity that prevents lactic acid generation (Johnson \& McClure, 1968), an aspect that needs further investigation in Agave plants.

Acetate concentrations of Agave silages were similar to those of silages of common plants (McDonald, 1981). This is an important characteristic of Agave silages because although lactic acid is the most desirable acid in ensiling, acetate enhances silage stability when the silo is opened and the content exposed to aerobic environmental condition (Holzer et al., 2003), because acetate is less dissociated than lactic acid, helping to prevent growth of undesirable microorganisms (Danner et al., 2003).

The silage process reduced the saponin concentration in Agave silages (from 6.1 to $3.4 \mathrm{~g} / \mathrm{kg} \mathrm{DM}$ ), which is similar to that reported in lucerne silages (Kalac et al., 1996). Agave saponins are mostly steroidal sapogenins bound to one or two sugar chains (Yang et al., 2006). This complex makes the saponin molecule an active compound, but when the sugar chains are separated the sapogenin molecule becomes an inactive compound (Wang et al., 2000; Singh et al., 2003). Francis et al. (2002) suggested that some saponins might be de-activated during the anaerobic fermentation of silage.

\section{Conclusion}

Upper and lower leaf sections of A. salmiana are a good source of soluble carbohydrates. However, the CP content is low which would require protein supplementation. Ensiling A. salmiana decreased its saponin concentration, and the silage fermentation characteristics are acceptable. The chemical composition suggests that the mature and bud stages are the most desirable stages of Agave to be utilized as a feed for ruminants.

\section{Acknowledgements}

This work was supported by: (i) Consejo Nacional de Ciencia y Tecnología (CONACYT project J39041-B); (ii) Fondo de Apoyo a la Investigación (FAI-UASLP); and (iii) International Centre for Agricultural Research in Dry Areas (ICARDA) and to the International Fund for Agricultural Development (IFAD, Project: Strengthening institutional capacity to improve marketing of small ruminant products and income generation in dry areas of Latin America).

\section{References}

Aguirre, J.R., Charcas, H. \& Flores, J.L., 2001. El Maguey Mezcalero Potosino. Universidad Autónoma de San Luis Potosí, San Luis Potosí. S.L.P., México.

AOAC, 1995. Official Methods of Analysis $\left(16^{\text {th }}\right.$ ed.). Association of Official Analytical Chemists, Arlington, VA., USA.

Baccou, J.C., Lambert, F. \& Sauvaire, Y., 1977. Spectrophotometric method for the determination of total sapogenin steroidal sapogenin. Analyst. 102, 458-465.

Cherney, D.J.R., Cherney, J.H. \& Cox, W.J., 2004. Fermentation characteristics of corn forage ensiled in mini-silos. J. Dairy Sci. 87, 4238-4246.

Danner, H., Holzer, M., Mayrhuber, E. \& Braun, R., 2003. Acetic acid increases stability of silage under aerobic conditions. Appl. Environ. Microbiol. 69, 562-567.

Davies, D.R., Merry, R.J., Williams, A.P., Bakewell, A.L., Leemans, D.K. \& Tweed, J.K., 1998. Proteolysis during ensilage of forages varying in soluble sugar content. J. Dairy Sci. 81, 444-453.

Dubois, M., Gilles, K.A., Hamilton, J.K., Roberts, P.A. \& Smith, F.F., 1956. Colorimetric method for determination of sugar and related substances. Anal. Chem. 28, 350-356. 
Erwin, E.S., Marco, G.J. \& Emery, E., 1961. Volatile fatty acid analysis of blood and rumen fluid by gas chromatography. J. Dairy Sci. 44, 1768-1771.

Francis, G., Kerem, Z., Makkar, H.P.S. \& Becker, K., 2002. The biological action of saponin in animal systems. Br. J. Nutr. 88, 587-605.

Fransen, S.C. \& Strubi, F.J., 1998. Relationships among absorbents on the reduction of grass silage effluent and silage quality. J. Dairy Sci. 81, 2633-2644.

Holzer, M., Mayrhuber, E., Danner, H. \& Braun, R., 2003. The role of Lactobacillus buchneri in forage preservation. Trends Biotechnol. 21, 282-287.

Iniguez-Covarrubias, G., Lange, S.E. \& Rowell, R.M., 2001. Utilization of byproducts from the tequila industry: part 2: potential value of Agave tequilana Weber azul leaves. Bioresour. Technol. 77, 101-108.

Johnson, L.M., Harrison, J.H. \& Davidson, D., 2002. Corn silage management: Effects of maturity, inoculation, and mechanical processing on pack density and aerobic stability. J. Dairy Sci. 85, 434-444.

Johnson, R.R. \& McClure, K.E., 1968. Corn plant maturity. IV. Effects on digestibility of corn silage in sheep. J. Anim. Sci. 27, 535-540.

Kalac, P., Price, K.R. \& Fenwick, G.R., 1996. Changes in saponin content and composition during the ensilage of alfalfa (Medicago sativa L.). Food Chem. 56, 377-380.

Madrid, J., Martinez-Teruel, A., Hernandez, F. \& Megías, M.D., 1999. A comparative study on the determination of lactic acid in silage juice by colorimetric, high-performance liquid chromatography and enzymatic methods. J. Sci. Food Agric. 79, 1722-1726.

McCullough, H., 1967. The determination of ammonia in whole blood by direct colorimetric method. Clin. Chem. Acta. 17, 297-304.

McDonald, P., 1981. The Biochemistry of Silage. John Wiley \& Sons, Chichester, England.

Mustafa, A.F., Seguin, P., Ouellet, D.R. \& Adelye, I., 2002. Effects of cultivars on ensiling characteristics, chemical composition, and ruminal degradability of pea silage. J. Anim. Sci. 85, 3411-3419.

Nobel, P.S. \& Meyer, S.E., 1985. Field productivity of a CAM plant, Agave salmiana, estimated using daily acidity changes under various environmental conditions. Physiol. Plant. 65, 397-404.

Pinos-Rodríguez, J.M., Aguirre-Rivera, J.R., García-López, J.C., Rivera-Miranda, M.T., González-Muñoz, S., López-Aguirre, S. \& Chávez-Villalobos, D., 2006. Use of "maguey" (Agave salmiana Otto ex. Salm-Dick) as forage for ewes. J. Appl. Anim. Res. 30, 101-107.

Pinos-Rodríguez, J.M., Gonzalez, S.S., Badillo, B., García-López, J.C., Aguirre-Rivera, J.R. \& Infante, S., 2007. Chemical composition and ruminal in vitro degradation of Agave salmiana Otto ex. Salm-Dick fresh or silage. J. Appl. Anim. Res. (In press).

Salisbury, F.B. \& Ross C.W., 1991. Plant Physiology. 4a ed. Wadsworth Publishing Company, Belmont, CA., USA.

SAS, 1999. Statistical Analysis Systems user's guide (Statistics, Version. 8). SAS Institute Inc, Cary, N.C. USA.

Savoie, S., Amyot, A. \& Thériault, R., 2002. Effect of moisture content, chopping, and processing on silage effluent. Transactions of the ASAE. 45, 907-914.

Silos-Espino, H., González-Cortes, N., Carrillo-López, A., Guevara-Lara, F., Valverde- González, M.E. \& Paredes-López, O., 2007. Chemical composition and in vitro propagation of Agave salmiana 'Gentry'. J. Hort. Sci. Biotechnol. 82, 355-359.

Singh, B., Bhat, T.J. \& Singh, B., 2003. Potential therapeutic applications of some antinutritional plant secondary metabolites. Agric. Food Chem. 5, 5581-5597.

Salinas, M.L., Ogura, T. \& Soffchi, L., 2001. Irritant contact dermatitis caused by needle-like calcium oxalate crystals, raphides, in Agave tequilana among workers in tequila distilleries and Agave plantations. Cont. Derm. 44, 94-96.

Van Soest, P.J., Robertson, P.J. \& Lewis, B.A., 1991. Methods for dietary fiber, neutral detergent fiber, and non-starch polysaccharides in relation to animal nutrition. J. Dairy Sci. 74, 3583-3597.

Van Soest, P.J., 1994. Nutritional Ecology of the Ruminant. 2nd ed. Cornell University Press. N.Y., USA.

Wang, Y., McAllister, T.A., Yanke, L.J. \& Cheeke, P.R., 2000. Effect of steroidal saponin from Yuca Schidigera stract in on ruminal microbes. J. Appl. Microbiol. 88, 887-896. 
Wang, N. \& Novel, P.S., 1998. Phloem transport of fructans in the Crassulacean acid metabolism species Agave deserti. Plant Physiol. 116, 709-714.

Yahaya, M.S., Kawai, M., Takahashi, J. \& Matsuoka, S., 2002. The effect of different moisture contents at ensiling on silo degradation and digestibility of structural carbohydrates of orchardgrass. Anim. Feed Sci. Technol. 101, 127-133.

Yang, C., Zhang, Y., Jacob, M.R., Klan, S.I. \& Zhang Y., 2006. Antifungal activity of c-27 steroidal saponin. Antimicrob. Agent Chemother. 50, 1710-1714. 